Available Online at ESci Journals

International Journal of Educational Studies

ISSN: 2312-458X (Online), 2312-4598 (Print)

http://www.escijournals.net/IJES

\title{
APPLICATION OF MATHEMATICAL MODELING TO STUDY THE POPULATION GROWTH OF SERGIPE
}

\author{
Romualdo S. S. Junior \\ Federal University of Sergipe Rosa Elze, São Cristóvão - SE, 49100-000, Brazil.
}

A B S T R A C T

Knowledge of population growth of a particular region is of great importance for the political interests are reassessed and refocused. The objective of this work is to use the Malthusian model that takes into account the mathematical tool of Differential equations, in particular the separation of variables, and apply to the study of population growth in the state of Sergipe. The results showed significantly close to the estimated values by the IBGE (Brazilian Institute of Geography and Statistics). It is observed, that the forecast population growth for Sergipe has de-creased, changing from continuous to a discrete model by the year 2050.

Keywords: Mathematical modeling, population growth of Sergi-pe, Malthusian model.

\section{INTRODUCTION}

The more clear and structured view of reality is undoubtedly a very old phenomenon modeling, as well as mathematics itself. This process of understanding comes from the interaction and application of daily thoughts of people from the most ancient times. Since ancient times, the search for explanations of certain specific problems are solved or minimized through the use of resources and mathematical procedures.

By way of interpretation, the men search for answers or even curiosity need to make estimates and numerical approximations, thus enabling formulation of mathematical models.

The use of mathematical modeling has an important role in the biological area (Almarcha et al., 1969), is applicable to the study of molecules, bacteria, cells, insects, among others.

The study of population growth in a given region is important for political, economic and cultural interests will be enhanced and again established in this society, so that it will encourage the future of the same.

A cutout on the state of Sergipe: The state of Sergipebegan to be colonized from the sixteenth century with the arrival of the French in their ships, where they

* Corresponding Author:

Email: romu.fisica@gmail.com

(C) 2014 ESci Journals Publishing. All rights reserved. exchanged their objects for Brazil wood, pepper and cotton. The idea of conquering the lands north of Bahia, Sergipe territory that is today, was an initiative of Garcia D'Avila, a large landowner in that region, with the help of the Jesuits tried to catechize the natives who were there. The colonization happened in 1590, in the village of Saint Christopher town today, giving way to the captaincy of Sergipe D'EI-King. The province of Sergipe only came to be one of the states of the federation in 1889 with the proclamation of the Republic and its first constitution was promulgated in 1892. In 1855 the capital of Sergipe was transferred to the city of Aracaju, due to ease of export and import, mobility and so on, and today the capital of Sergipe. The name came from the Tupi Sergipe si'ri ü PE which means "of the river crabs", and later adopted as Cerizipe, name of a chieftain who opposed the Portuguese rule.

Sergipe is located east of the northeast region of Brazil and presents a territorial range of approximately $22050.4 \mathrm{~km} 2$, being the smallest state of the federation. It features a relief that is characterized with low lands and plains of the nearest coastline, its climate is tropical on the coast with frequent rains and long droughts in semi-arid region, average temperatures range from 23 to $25^{\circ} \mathrm{C}$ (Brauere et al., 1967) Today, Sergipe involves a little more than 2 million inhabitants distributed in 75 municipalities, most of them inhabitants of large cities, 
where about $51 \%$ of the inhabitants are women and $49 \%$ men. The population growth of Sergipe, in the period 1940 to 2010, had an exponential increase of about 1.5 million inhabitants. Somehow this growth had influence population dynamics, i.e., the vast majority of people migrated to urban areas in search of more easily and job search through large industries and trade.

A curious fact, and particularly the State of Sergipe is that until the 1920, Sergipe been registering a percentage of population growth below the northeast and Brazil from the 1970 began firing equaling the growth of the northeast, and finally the following decades came to exceed that percentage, as both the northeast of Brazil (Edelstein-Keshet et al., 1988)

The objective of this work is to show the application of mathematical modeling as an alternative to the study of population growth Sergipe, where it will be considered the Malthusian model, proposed by Thomas Malthus (1776-1834).

\section{MALTHUSIAN MODEL}

One of the most common ways to model a given population is using the model of Malthus called Malthusian (Pugens et al., 2012) model. This model is very simple which is formed by a derivable function $\delta$, and that increases with a proportional rate to the population size.

The Malthus model is based primarily on two postulates:

1. "The food is necessary to the subsistence of man";

2. "The passion between the sexes is necessary and will remain nearly in its permanent state."

Assuming, that these two postulates are correct and secured, I will consider as already proposed in the Malthusian model of population growth life is optimized, i.e., there is no war, famine, epidemics or any other disaster, where all individuals are exactly identical and have the same behavior.

When we consider that the rate at which a population grows is proportional to its size, means in the form of differential equations that:

$$
\frac{d \delta}{d t}=k \delta
$$

Where $k=A-B$, which represents the difference between the birth rate and mortality rate of the population.

If $k>0$ means that the population has an increased growth, if $k<0$ the population declines over time, however, if $k=0, A=B$ (birth rate equal to the rate of mortality) a population will remain constant at time ( $\mathrm{t}$ ). To arrive at an equation that models the population over time, or according to a temporal variation write equation (1) as a separable differential equation:

$$
\frac{d \delta}{\delta}=k d t
$$

Where the general solution to this equation is given:

$$
\delta(t)=\delta_{0} e^{k t}
$$

The equation (3) is written in exponential form that describes and represents population growth exponentially function.

We have a constant $\mathrm{k}$ that can only be solved if we know any given population at a later time, remembering that $k$ $=A-B$, which represents the difference between the birth rate and mortality, $\mathrm{k}$ being a constant value with time in solving this problem.

Calculating the rate of population growth: To calculate the rate of population growth, we consider that birth rates (A) and mortality (B) are constant in time.

Thus,

$$
\frac{\delta(t+1)-\delta(t)}{\delta(t)}=A-B=k
$$

Equation (4) is the relative population variation, which is constant, i.e., that change is proportional to the population itself in each time period.

Where,

$$
\delta(t+1)-\delta(t)=k \delta(t)
$$

Assuming that at an initial time $\mathrm{t}=0$ the initial population is $\delta(0)=\delta 0$, the solution of equation (4) is obtained from the expression:

$$
\left\{\begin{array}{l}
\delta(t+1)=(1+k) \delta(t) \\
\delta(0)=\delta_{0}
\end{array}\right.
$$

Soon,

$$
\delta_{t}=(1+k)^{t} \delta_{0}
$$

So knowing two censuses $\delta 0$ and $\delta$ t of a population, we find the growth rate at a certain time $t$ using equation (7), causing:

$$
\begin{gathered}
\frac{\delta_{t}}{\delta_{0}}=(1+k)^{t} \\
k^{t}=\frac{\delta_{t}}{\delta_{0}}-1^{t} \\
k=\sqrt[t]{\frac{\delta_{t}}{\delta_{0}}}-1
\end{gathered}
$$

Substituting (10) into (3), we find the expression for the dependent population growth only time. 
Int. J. Educ. Stud. 01 (03) 2014. 119-123

$$
(\mathrm{t}): \delta(t)=\delta_{0} e^{\left[\sqrt[\left[\sqrt{\frac{\delta_{t}}{\delta_{0}}}-1\right] t]{t}\right.}
$$

\section{RESULTS AND DISCUSSION}

The following table shows the population growth of Sergipe and the rate at which it occurs between the years 1940 and 2010.

Table I. Populación growth of Sergipe. Populación number is by IBGE.

\begin{tabular}{ccc}
\hline Year & $\begin{array}{c}\text { Population } \\
\text { number }\end{array}$ & $\begin{array}{c}\text { Population } \\
\text { growth rate }(\%)\end{array}$ \\
\hline 1940 & 542326.0 & 14.0 \\
1950 & 644361.0 & 19.0 \\
1960 & 760273.0 & 18.0 \\
1970 & 911251.0 & 20.0 \\
1980 & 1156642.0 & 27.0 \\
1991 & 1491867.0 & 29.0 \\
2000 & 1781714.0 & 19.0 \\
\hline
\end{tabular}

Based on the data in Table 1, from the IBGE census [10], which in 1940 had a population of Sergipe $\delta 0=$ 542326.0 thousand inhabitants, and ten years after $\delta 10$ $=644361.0$ thousand inhabitants, the rate of average population growth for the period 1940 to 1950 is given by:

$$
k=\sqrt[10]{\frac{644326.0}{542361.0}}-1=0.0174
$$

I.e., an annual growth of approximately $1.7 \%$. If we now consider the period 1970 to 1980 found that:

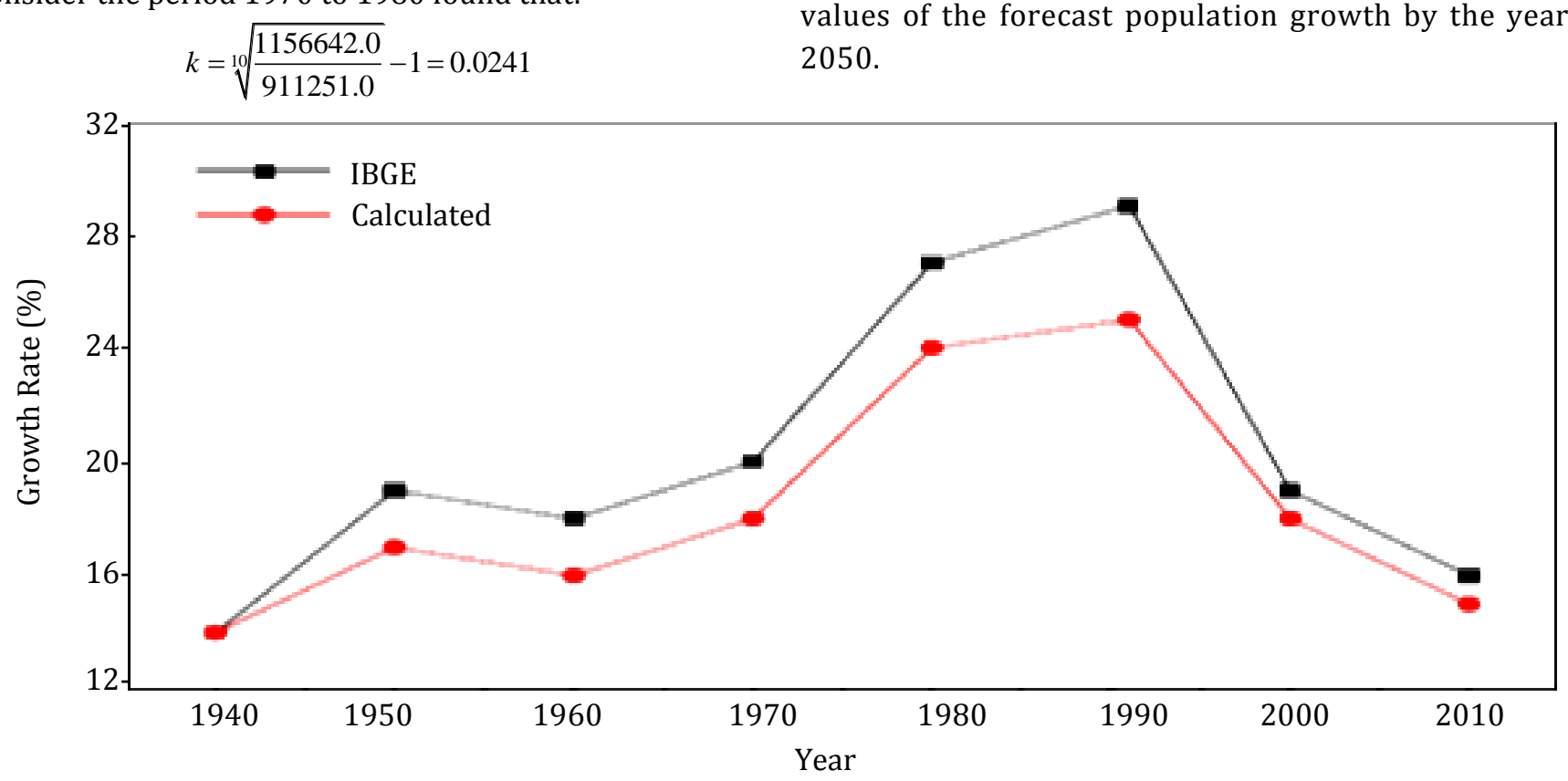

Fig 1. Graph the population growth rate according to the IBGE (Black) and the graph of population growth rate calculated with the Malthusian model (red). 
Int. J. Educ. Stud. 01 (03) 2014. 119-123

Table 3. Population growth estimate for the Sergipe 2050 calculated by the Malthusian model.

\begin{tabular}{ccc}
\hline Year & Population number & $\begin{array}{c}\text { Population growth } \\
\text { rate (\%) }\end{array}$ \\
\hline 2020 & 2285819.0 & 10.0 \\
2030 & 2503231.0 & 9.1 \\
2040 & 2728522.0 & 8.6 \\
2050 & 2926536.0 & 7.0 \\
\hline
\end{tabular}

Table 3 shows the calculated values of population numbers and growth rate for the state of Sergipe in the next few decades, until the year 2050, more specifically. We can then construct a graph to prove it growth performance estimated by calculations using the model, which can serve as a basis for analysis of the rulers in order to judge whether or not this growth can be detrimental to the state of Sergipe.

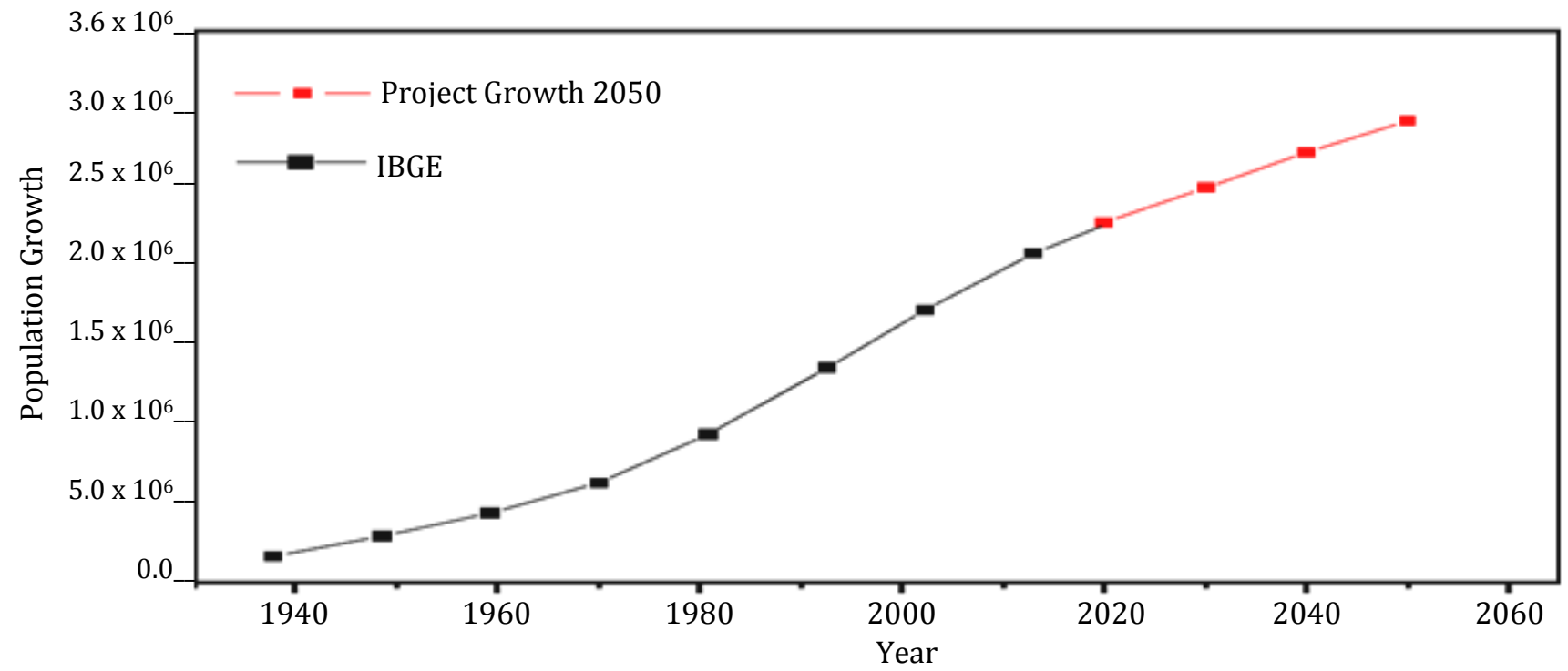

Fig 2. Graph of Projection of population growth calculated Sergipe 2050.

A decrease in populación growth for the coming decades can be observed. Figure 2 shows the graph of population growth projection of Sergipe through the calculation performed by the year 2050, which shows an increase in growth of approximately $35 \%$ compared to 2010 . Can be seen, in the graph of Figure 2, the estimation of population growth for Sergipe shows a decrease in the coming decades, by 2050, where the Malthusian model now can no longer be applied, since the model describes very well a population growth continuous, not a discrete behavior.

\section{CONCLUSION}

Thus, we can conclude that the application of mathematical modeling through the Malthusian model can be an alternative implementation to the study of population growth in the state of Sergipe, since our findings showed a significant proximity and those published by the IBGE (Brazilian Institute of Geography and Statistics).

It can be seen that the estimation of population growth for Sergipe shows a decrease in the coming decades, until 2050, where the Malthusian model now can no longer be applied, since the model describes very well a population growth continuous, not a discrete behavior.

Hopefully, this work is of great benefit to the authorities concerned are benefited with great care and analyze the results obtained here. Also show that the mathematical modeling is very important for understanding the issues that govern our lives, since this type of analysis serves as a supplement to the organ interested in understanding population behavior.

\section{REFERENCES}

Almarcha, A. A. de Miguel, J. de Miguel y J. L. Romero. (1969). La documentación y organización de los datos em la investigación sociologica. Madrid, Confederación Española de Cajas de Ahorros,.

Almeida, I.A. (2003) "Aplicação dos Modelos de Malthus e Verhulst de Dinâmica Populacional a População do Brasil", Tese de Doutorado, Catalão-UFG,.

Dennis, G. Zill. (2011) Equações Diferenciais com Aplicações em Modelagem. Thomson, São Paulo, 2a. edição.

Brauere J. A. (1967). Nohel: Ordinary Differential Equations: A First Course. W. A. Benjamin, Inc., New York. 
Int. J. Educ. Stud. 01 (03) 2014. 119-123

Edelstein-Keshet, L., Mathematical Models in Biology. (1988). New York: Random House.

IBGE (Brazilian Institute of Geography and Statistics). Available at: http://www.ibge.gov.br

Pugens B.P., J. F. da Silva, R. da R. Fernandes e D. S. Godinho. (2012). Modelos matemáticos que descrevem o crescimento populacional: aplicadose contextualizados aos dados do município de Osório. Revista ModelosFACOS/CNECOsório. Ano 2, Vol. 2, N 2:525

Ricardo Lacerda. (2012) Blog Development Scenarios. Available at:http://cenariosdesenvolvimento. blogspot.com.br.

The state of Sergipe. Available at: http://www.dc.mec.gov.br/imagens-e-textos/ revista3 -mat11.pdf. 